\title{
DEMOCRATIC INCLUSION
}

\section{Rainer Bauböck}

IN DIALOGUE

CRITICAL POWERS SERIES 


\section{Democratic inclusion}

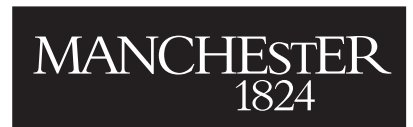

Manchester University Press 


\section{CRITICAL POWERS}

\section{Series Editors:}

Bert van den Brink (University of Utrecht), Antony Simon Laden (University of Illinois, Chicago),

Peter Niesen (University of Hamburg) and

David Owen (University of Southampton).

Critical Powers is dedicated to constructing dialogues around innovative and original work in social and political theory. The ambition of the series is to be pluralist in welcoming work from different philosophical traditions and theoretical orientations, ranging from abstract conceptual argument to concrete policy-relevant engagements, and encouraging dialogue across the diverse approaches that populate the field of social and political theory. All the volumes in the series are structured as dialogues in which a lead essay is greeted with a series of responses before a reply by the lead essayist. Such dialogues spark debate, foster understanding, encourage innovation and perform the drama of thought in a way that engages a wide audience of scholars and students.

\section{Published by Bloomsbury}

On Global Citizenship, James Tully

Justice, Democracy and the Right to Justification, Rainer Forst

\section{Published by Manchester University Press}

Cinema, democracy and perfectionism: Joshua Foa Dienstag in dialogue, Joshua Foa Dienstag (ed)

\section{Forthcoming from Manchester University Press}

Rogue Theodicy - Politics and power in the shadow of justice, Glen Newey Law and Violence, Christoph Menke Autonomy Gaps, Joel Anderson

Toleration, Liberty and the Right to Justification, Rainer Forst 


\title{
Democratic inclusion
}

\section{Rainer Bauböck in dialogue}

\author{
Rainer Bauböck \\ with responses from: \\ Joseph H. Carens \\ Sue Donaldson \\ Iseult Honohan \\ Will Kymlicka \\ David Miller \\ David Owen \\ Peter Spiro
}

Manchester University Press 
Copyright (c) Manchester University Press 2018

While copyright in the volume as a whole is vested in Manchester University Press, copyright in individual chapters belongs to their respective authors.

This electronic version has been made freely available under a Creative Commons (CC-BY-NC-ND) licence, which permits non-commercial use, distribution and reproduction provided the author(s) and Manchester University Press are fully cited and no modifications or adaptations are made. Details of the licence can be viewed at https://creativecommons.org/ licenses/by-nc-nd/3.0/

Published by Manchester University Press Altrincham Street, Manchester M1 7JA www.manchesteruniversitypress.co.uk

British Library Cataloguing-in-Publication Data

A catalogue record for this book is available from the British Library

$$
\begin{gathered}
\text { ISBN } 9781526105226 \text { hardback } \\
\text { ISBN } 9781526105233 \text { paperback } \\
\text { ISBN } 9781526105257 \text { open access }
\end{gathered}
$$

First published 2018

The publisher has no responsibility for the persistence or accuracy of URLs for any external or third-party internet websites referred to in this book, and does not guarantee that any content on such websites is, or will remain, accurate or appropriate.

Typeset

by Toppan Best-set Premedia Limited 